\title{
Contrasts in the multiple causes of stillbirth, neonatal death and postneonatal death
}

\author{
M MURPHY ${ }^{1}$ AND B BOTTING ${ }^{2}$ \\ From ${ }^{1}$ the Department of Community Medicine and General Practice, Radcliffe Infirmary, Oxford; and ${ }^{2}$ the \\ Medical Statistics Division, OPCS, London WC2.
}

ABSTRACT A large sample of stillbirth and infant death certificates for England and Wales from 1979-81 was analysed for the frequency of appearance of maternal and fetal conditions anywhere on the certificate, not just as the underlying cause. The results suggest there is presently no need to extend the use of the new stillbirth and neonatal death certificates, introduced in 1986, to the postneonatal period. Periodic multicause analysis of the old style death certificate should be sufficient to reveal the detail of conditions incriminated in postneonatal deaths.

On 1st January 1986 new forms for the certification of stillbirth and neonatal death were introduced in England and Wales. These are in the form recommended by the 29th World Health Assembly and are designed to encourage the certifiers to record conditions in both the mother and the baby contributing to the death, rather than to provide a sequence of causes leading to death. ${ }^{1}$ Since the data have both maternal and fetal dimensions it will no longer be possible to derive a single underlying cause, and attention will necessarily be directed to every condition mentioned on the certificate. This practice was previously followed only for conditions of recurrent interest such as hypothermia and Sudden Infant Death Syndrome where the underlying cause statistics are known to be of dubious validity. The rountine publication of stillbirth and neonatal death statistics by the Office of Population Censuses and Surveys (OPCS) in the DH3 series, derived from use of the new certificates, will only begin early in 1989 . To provide an approximate baseline for these future analyses and in response to the suggestion that perinatally determined conditions are becoming increasingly important in postneonatal deaths, ${ }^{23}$ we have analysed the distribution of maternal and fetal conditions mentioned anywhere on the pre-1986 old style certificates for a sample of stillbirth and infant deaths.

\section{Methods}

From time to time in the past, resources permitting, OPCS has for a sample of stillbirths and infant deaths in England and Wales coded every condition mentioned anywhere in either part I or II of the certificates, not just the underlying cause. For stillbirths these data were available for the two complete years $1979(n=5125)$ and $1980(n=4773)$. For 675 of these 9898 occurrences, gestational age was not known and we have excluded them from the analysis. For the infant deaths, varying proportions were coded in the years 1979-81. For 19793579 records were available, based on $25 \%$ coding from January to September and $100 \%$ for the remainder of the year. In 1980, there was $100 \%$ coding yielding 5111 records. For 1981, the intention to code $100 \%$ January to June and $25 \%$ July to December was interrupted by an industrial dispute involving local registrars, and as a result only 610 records were available from $100 \%$ coding of the first 2 months of the year. Of a total 9300 infant records coded, 9200 were available for analysis.

\section{Results}

The table shows the numbers of babies involved, the number of times conditions in broad cause groups were mentioned on their certificates, and the average number of mentions per baby. For stillbirths gestational age is recorded at birth registration and we have stratified on this variable, but for infant deaths this information is not collected. More complicated tabulations by other social and biological factors, eg, social class, birthweight or parity, were not feasible with the particular unlinked deaths computer file that had been multicause coded. It can be seen that the average number of conditions mentioned as contributing to the death is greatest for babies dying in the neonatal period. As would be expected, the pattern 
Table Multicause coded stillbirths and infant deaths by cause and gestation/age at death: numbers (percentage) in each cause group 1979-81, England and Wales

\begin{tabular}{|c|c|c|c|c|c|c|c|}
\hline \multirow{2}{*}{$\begin{array}{l}\text { Cause } \\
\text { group }\end{array}$} & \multirow[b]{2}{*}{$I C D 9$} & \multirow[b]{2}{*}{ Cause } & \multicolumn{3}{|c|}{$\begin{array}{l}\text { Stillbirths } \\
\text { gestation (weeks) }\end{array}$} & \multirow{2}{*}{$\begin{array}{l}\text { Neonatal } \\
\text { deaths }\end{array}$} & \multirow{2}{*}{$\begin{array}{l}\text { Postneonatal } \\
\text { deaths }\end{array}$} \\
\hline & & & $28-32$ & $33-36$ & $37+$ & & \\
\hline & & All mentions & $\begin{array}{l}5275 \\
(100)\end{array}$ & $\begin{array}{l}5058 \\
(100)\end{array}$ & $\begin{array}{l}7030 \\
(100)\end{array}$ & $\begin{array}{r}13197 \\
(100)\end{array}$ & $\begin{array}{l}6238 \\
(100)\end{array}$ \\
\hline 1 & 7600,642 & Maternal hypertension & $\begin{array}{l}430 \\
(8 \cdot 2)\end{array}$ & $\begin{array}{l}362 \\
(7 \cdot 2)\end{array}$ & $\begin{array}{l}280 \\
(4 \cdot 0)\end{array}$ & $\begin{array}{c}43 \\
(0 \cdot 3)\end{array}$ & $\begin{array}{c}1 \\
(0 \cdot 02)\end{array}$ \\
\hline 2 & $760 \mathrm{rem}$ & $\begin{array}{l}\text { Other maternal conditions related to } \\
\text { present pregnancy }\end{array}$ & $\begin{array}{l}105 \\
(2 \cdot 0)\end{array}$ & $\begin{array}{c}96 \\
(1.9)\end{array}$ & $\begin{array}{l}90 \\
(1 \cdot 3)\end{array}$ & $\begin{array}{l}17 \\
(0 \cdot 1)\end{array}$ & $\begin{array}{c}1 \\
(0 \cdot 02)\end{array}$ \\
\hline 3 & 7615 & Multiple pregnancy & $\begin{array}{l}175 \\
(3 \cdot 3)\end{array}$ & $\begin{array}{l}199 \\
(3 \cdot 9)\end{array}$ & $\begin{array}{l}198 \\
(2 \cdot 8)\end{array}$ & $\begin{array}{c}249 \\
(1 \cdot 9)\end{array}$ & $\begin{array}{c}3 \\
(0 \cdot 05)\end{array}$ \\
\hline 4 & 761 rem & $\begin{array}{l}\text { Other maternal complications of } \\
\text { pregnancy }\end{array}$ & $\begin{array}{l}112 \\
(2 \cdot 1)\end{array}$ & $\begin{array}{c}69 \\
(1.4)\end{array}$ & $\begin{array}{c}61 \\
(0 \cdot 9)\end{array}$ & $\begin{array}{r}50 \\
(0 \cdot 4)\end{array}$ & $\begin{array}{l}0 \\
(0)\end{array}$ \\
\hline 5 & $\begin{array}{l}7620,7621 \\
641\end{array}$ & Maternal haemorrhage & $\begin{array}{c}699 \\
(13 \cdot 3)\end{array}$ & $\begin{array}{l}606 \\
(12 \cdot 0)\end{array}$ & $\begin{array}{l}473 \\
(6 \cdot 7)\end{array}$ & $\begin{array}{l}112 \\
(0 \cdot 8)\end{array}$ & $\begin{array}{c}4 \\
(0.06)\end{array}$ \\
\hline 6 & 762 rem & $\begin{array}{l}\text { Other complications of placenta, cord, } \\
\text { membranes }\end{array}$ & $\begin{array}{c}803 \\
(15 \cdot 2)\end{array}$ & $\begin{array}{c}927 \\
(18 \cdot 3)\end{array}$ & $\begin{array}{l}1628 \\
(23 \cdot 2)\end{array}$ & $\begin{array}{l}74 \\
(0 \cdot 6)\end{array}$ & $\begin{array}{c}4 \\
(0 \cdot 06)\end{array}$ \\
\hline 7 & 763 & Complications of labour and delivery & $\begin{array}{c}80 \\
(1 \cdot 5)\end{array}$ & $\begin{array}{c}55 \\
(1 \cdot 1)\end{array}$ & $\begin{array}{l}210 \\
(3 \cdot 0)\end{array}$ & $\begin{array}{l}94 \\
(0 \cdot 7)\end{array}$ & $\begin{array}{c}1 \\
(0.02)\end{array}$ \\
\hline 8 & 740 & Anencephalus & $\begin{array}{l}286 \\
(5 \cdot 4)\end{array}$ & $\begin{array}{l}285 \\
(5 \cdot 6)\end{array}$ & $\begin{array}{l}191 \\
(2 \cdot 7)\end{array}$ & $\begin{array}{r}72 \\
(0 \cdot 5)\end{array}$ & $\begin{array}{c}1 \\
(0 \cdot 02)\end{array}$ \\
\hline 9 & 741 & Spina bifida & $\begin{array}{c}93 \\
(1 \cdot 8)\end{array}$ & $\begin{array}{c}89 \\
(1 \cdot 8)\end{array}$ & $\begin{array}{l}163 \\
(2 \cdot 3)\end{array}$ & $\begin{array}{c}394 \\
(3 \cdot 0)\end{array}$ & $\begin{array}{l}125 \\
(2 \cdot 0)\end{array}$ \\
\hline 10 & 7420 & Encephalocele & $\begin{array}{c}10 \\
(0 \cdot 2)\end{array}$ & $\begin{array}{c}15 \\
(0 \cdot 3)\end{array}$ & $\begin{array}{l}19 \\
(0 \cdot 3)\end{array}$ & $\begin{array}{c}57 \\
(0 \cdot 4)\end{array}$ & $\begin{array}{c}8 \\
(0 \cdot 1)\end{array}$ \\
\hline 11 & 742 rem & Other CNS defects & $\begin{array}{c}81 \\
(1 \cdot 5)\end{array}$ & $\begin{array}{l}118 \\
(2 \cdot 3)\end{array}$ & $\begin{array}{l}249 \\
(3 \cdot 5)\end{array}$ & $\begin{array}{c}278 \\
(2 \cdot 1)\end{array}$ & $\begin{array}{l}152 \\
(2 \cdot 4)\end{array}$ \\
\hline 12 & $745-7$ & Cardiovascular anomalies & $\begin{array}{c}25 \\
(0 \cdot 5)\end{array}$ & $\begin{array}{c}44 \\
(0 \cdot 9)\end{array}$ & $\begin{array}{c}38 \\
(0 \cdot 5)\end{array}$ & $\begin{array}{l}978 \\
(7 \cdot 4)\end{array}$ & $\begin{array}{l}609 \\
(9 \cdot 8)\end{array}$ \\
\hline 13 & $740-759$ rem & Other congenital anomalies & $\begin{array}{l}295 \\
(5 \cdot 6)\end{array}$ & $\begin{array}{l}298 \\
(5 \cdot 9)\end{array}$ & $\begin{array}{l}302 \\
(4 \cdot 3)\end{array}$ & $\begin{array}{l}1429 \\
(10 \cdot 8)\end{array}$ & $\begin{array}{l}300 \\
(4 \cdot 8)\end{array}$ \\
\hline 14 & $764-5$ & Prematurity & $\begin{array}{l}420 \\
(8 \cdot 0)\end{array}$ & $\begin{array}{l}183 \\
(3 \cdot 6)\end{array}$ & $\begin{array}{c}92 \\
(1 \cdot 3)\end{array}$ & $\begin{array}{l}2982 \\
(22 \cdot 6)\end{array}$ & $\begin{array}{l}127 \\
(2 \cdot 0)\end{array}$ \\
\hline 15 & 767 & Birth trauma & $\begin{array}{c}19 \\
(0 \cdot 4)\end{array}$ & $\begin{array}{c}11 \\
(0 \cdot 2)\end{array}$ & $\begin{array}{c}64 \\
(0 \cdot 9)\end{array}$ & $\begin{array}{l}472 \\
(3 \cdot 6)\end{array}$ & $\begin{array}{c}21 \\
(0 \cdot 3)\end{array}$ \\
\hline 16 & 768 & Birth asphyxia & $\begin{array}{l}686 \\
(13 \cdot 0)\end{array}$ & $\begin{array}{c}699 \\
(13 \cdot 8)\end{array}$ & $\begin{array}{l}1514 \\
(21 \cdot 5)\end{array}$ & $\begin{array}{c}712 \\
(5 \cdot 4)\end{array}$ & $\begin{array}{c}22 \\
(0 \cdot 4)\end{array}$ \\
\hline 17 & $\begin{array}{l}769,770 \\
512,514 \\
516,518-9\end{array}$ & Respiratory disorders & $\begin{array}{c}22 \\
(0 \cdot 4)\end{array}$ & $\begin{array}{c}8 \\
(0 \cdot 2)\end{array}$ & $\begin{array}{c}77 \\
(1 \cdot 1)\end{array}$ & $\begin{array}{l}2349 \\
(17 \cdot 8)\end{array}$ & $\begin{array}{l}263 \\
(4 \cdot 2)\end{array}$ \\
\hline 18 & $\begin{array}{l}001-139 \\
320-326 \\
460-511 \\
513,771\end{array}$ & $\begin{array}{l}\text { Infections (including CNS } \\
\text { and respiratory) }\end{array}$ & $\begin{array}{c}26 \\
(0 \cdot 5)\end{array}$ & $\begin{array}{c}14 \\
(0 \cdot 3)\end{array}$ & $\begin{array}{c}10 \\
(0 \cdot 1)\end{array}$ & $\begin{array}{c}627 \\
(4 \cdot 8)\end{array}$ & $\begin{array}{l}1405 \\
(22 \cdot 5)\end{array}$ \\
\hline 19 & $766,772-9$ & Other perinatal causes & $\begin{array}{c}883 \\
(16 \cdot 7)\end{array}$ & $\begin{array}{c}963 \\
(19 \cdot 0)\end{array}$ & $\begin{array}{l}1328 \\
(18 \cdot 9)\end{array}$ & $\begin{array}{l}1377 \\
(10 \cdot 4)\end{array}$ & $\begin{array}{l}102 \\
(1 \cdot 6)\end{array}$ \\
\hline 20 & $\begin{array}{l}4275,428 \\
584-6, \\
780-999\end{array}$ & $\begin{array}{l}\text { Modes of death, ill defined } \\
\text { conditions, injury, poisoning }\end{array}$ & $\begin{array}{c}9 \\
(0 \cdot 2)\end{array}$ & $\begin{array}{c}8 \\
(0 \cdot 2)\end{array}$ & $\begin{array}{c}23 \\
(0 \cdot 3)\end{array}$ & $\begin{array}{l}453 \\
(3 \cdot 4)\end{array}$ & $\begin{array}{l}2327 \\
(37 \cdot 3)\end{array}$ \\
\hline 21 & Remainder & Other conditions & $\begin{array}{c}16 \\
(0 \cdot 3)\end{array}$ & $\begin{array}{c}9 \\
(0 \cdot 2)\end{array}$ & $\begin{array}{c}20 \\
(0 \cdot 3)\end{array}$ & $\begin{array}{c}378 \\
(2 \cdot 9)\end{array}$ & $\begin{array}{c}762 \\
(12 \cdot 2)\end{array}$ \\
\hline & & $\begin{array}{l}\text { Total number of babies } \\
\text { Ratio of mentions/babies }\end{array}$ & $\begin{array}{c}2765 \\
1.91\end{array}$ & $\begin{array}{c}2680 \\
1.89\end{array}$ & $\begin{array}{c}3778 \\
1.86\end{array}$ & $\begin{array}{l}5774 \\
2 \cdot 29\end{array}$ & $\begin{array}{c}3426 \\
1.82\end{array}$ \\
\hline
\end{tabular}

of conditions mentioned changes most dramatically with the transition between stillbirths and infant deaths, though there are also differences between the neonatal and postneonatal period. In general, maternal conditions (cause groups 1-7) form the highest proportion of all mentions amongst stillbirths at the earliest gestations and decrease steadily with older age at death. For some of these conditions such as maternal hypertension and haemorrhage, the gradient is marked. For the fetal conditions however (cause groups 8-21) there is little evidence of a consistent pattern of this sort, with the predictable exception of anencephaly. A considerable number of postneonatal mentions are counted in the "other" 
cause, group 21; although not shown in detail, this group includes a substantial number of fetal conditions which are hereditary or non-perinatally acquired.

\section{Discussion}

The data indicate some of the complexities in analysing multicause coded death certificates. In the absence of the possibly spurious accuracy of underlying cause rates, a different approach to the analysis of these statistics is necessary. Options include calculating the average number of mentions per baby or specific mentions as a proportion of total mentions. This will be made more complex since the new certificates require separate statements of main and other conditions contributing to the death, identified separately as being present in the baby or the mother. Nevertheless it is hoped that the form of the new certificates will assist certifiers to state their understanding of the circumstances surrounding the death and the contribution of maternal factors. ${ }^{2} 4$

It has been suggested that the form of the new certificates should be extended to the whole of infancy. ${ }^{2}$ However from our analysis of sample data it seems that in England and Wales in 1979-81 a very small number of postneonatal deaths were attributable to maternal causes and, with the exception of congenital anomalies, only a small proportion of the postneonatal deaths were associated with perinatal causes. These results are in agreement with those of a previous analysis of underlying cause statistics. ${ }^{5}$ In contrast, an assessment of postperinatal mortality in Glasgow 1979-81 suggested that half of these deaths were linked to maternal or perinatal conditions, but here the analysis was not restricted to death certificate information and of course included deaths under 4 weeks of age. ${ }^{3}$
In conclusion, there does not seem to be good enough reason for extending the use of the new form of the certificates to the postneonatal period, unless, through changes in neonatal care, much larger numbers of deaths which would previously have occurred in the neonatal period come to be postponed until later in infancy. For the whole of 1985 and 1986 OPCS has again coded all conditions mentioned as contributing to postneonatal deaths, and we feel that periodic multicause analysis of the postneonatal deaths should suffice to reveal the conditions stemming from the attributed underlying cause and any other conditions stated in part II of the certificate.

We would like to thank Christine Hoad of the Department of Community Medicine and General Practice, Oxford, for typing the manuscript.

Address for correspondence and reprints: $\mathrm{Dr} M$ Murphy, Clinical Lecturer in Community Medicine, Department of Community Medicine and General Practice, Radcliffe Infirmary, Oxford OX2 6HE, UK.

\section{References}

${ }^{1}$ Gedalla B, Alderson M. Pilot study of revised stillbirth and neonatal death certificates. Arch Dis Child 1984; 59: 976-82.

${ }^{2}$ Scott M. Certifying death in infancy. Br Med J 1984; 289: 1511-2.

${ }^{3}$ Arniel G, Brooke H, Gibson A, Harvie A, McIntosh M, Patrick W. Post perinatal mortality in Glasgow 1979-81. Lancet 1982; ii: 649-51.

${ }^{4}$ Scott M, Ritchie J, McClive B, McCreid M, Halliday $\mathbf{H}$. Perinatal death recording; time for a change? $\mathrm{Br}$ Med $J$ 1981; 282: 707-10.

5 Alderson M, Botting B, Murphy $\mathbf{M}$. Certifying death in infancy. $\mathrm{Br} \mathrm{Med} J$ 1985; 290: 153.

Accepted for publication April 1989 